\title{
Special issue on "Rights-based governance and decent work for migrants: a global perspective"
}

\author{
Nicola Piper ${ }^{1} \cdot$ Elspeth H. Guild ${ }^{1}$
}

Accepted: 1 September 2021 / Published online: 9 September 2021

(c) The Author(s), under exclusive licence to Institute for Global Public Policy, Fudan University 2021

The aim of this special issue, which is about the theme of emerging global migration governance and public policy in relation to labour migration, is to bring a new and critical perspective to global migration studies. The majority of international migration is related to labour either directly (people moving in search of work) or indirectly (refugees who seek protection but need also to work). In 2018, the United Nations (UN) brought together the international community to adopt two new instruments setting out a plan for the 21 st century on the treatment of migrants and refugees. These two instruments, the Global Compact for Refugees and the Global Compact for Safe, Orderly and Regular Migration (the Marrakesh Compact), received overwhelming support among states in the General Assembly (President Trump's USA being a rare example of disaccord). The objective of the two instruments is to establish as a primary objective in the management of refugee movements and migration the common responsibility of states to ensure dignity for those on the move and human rights protection under the conditions of rule of law. The key international organisations engaging with migration, the United Nations High Commissioner for Refugees (UNHCR), the International Labour Organisation (ILO), the High Commissioner for Human Rights and the International Organisation for Migration (IOM), all contributed centrally to the negotiation of the two instruments and have taken leading roles in their implementation by states. As the contributions to this issue demonstrate however, international organisations and states are not the only actors in this multi-layered, multi-sited policy field. Its multi-actor character requires cooperation and coordination across policy fields and levels of policymaking (national, regional, global) but at times also involves clashes and discord, for example in relation to meeting specific objectives or the use of certain types of strategies.

In this issue, we bring together critical voices from scholars with research experience of various countries and regions around the world, to examine the current state of labour migration from the perspective of the objectives endorsed

Nicola Piper

n.piper@qmul.ac.uk

1 Queen Mary University of London, London, UK 
and pursued by the international community in 2018. The particular focus is on 'decent work' for migrants in its manifold manifestations. From the perspective of labour migration or migration with work as a central component, the vulnerability of migrants and the precarious state in which they find themselves, is created and expressed by state mechanisms of control in relation to their national labour markets which are linked to transnationally operating mediators such as recruiters and subject to global regulatory frameworks such as the standards by the ILO. While the international community has been willing to sign up to the Global Compacts and participate in the ILO's campaign designed to promote decent work, one problem area concerns national implementation on the ground. This scenario raises the question about gaps between international commitments and national measures to protect the domestic labour market (addressed by Guild and Barylska, this volume). The overarching questions raised in this issue relates to how to advance a 'decent work' agenda for migrants in light of the widespread occurrence of un-decent work (forced labour, exploitation and labour rights violations) and the institutional complexity the governance of migration has reached?

There are seven contributions to this special issue, each addressing this question from a different angle and a different discipline. This original approach brings a truly inter-disciplinary perspective to a field of transnational movement of persons which is all too often imprisoned in single disciplines and national frameworks. This special issue breaks that mould and enables a discussion between disciplines and regions which enriches the subject and through the inter-relationship creates new knowledge about a complex and politically sensitive field.

In the first article, Gordon examines one of the flagship labour migration policies of the 21st century: the attempt to transform Syrian refugees into labour migrants in Jordan. This effort was the subject of a Pact in 2016 promoted by a number of Western states and supported by the UN. The article examines the implementation of this Pact and analyses the successes and failures in the context of the objectives of the promoters primarily to stabilise the Syrian refugee population in Jordan and avoid onwards migratory movements towards Europe. Her paper demonstrates how the two above mentioned Compacts reinforce the division between the 'refugee regime' and the 'labour migration' regime, manifested in separate institutions in charge (UNHCR, ILO) reinforcing the lack of alignment and cross-expertise engagement. The losers are not only refugees but also local workers.

In the paper that follows, Piper and Foley take the issue of synergies and competition among international organisations engaged in the field of labour migration in another direction: by analysing the relationship between the ILO and IOM in the pursuit of decent work for migrants by forming partnerships. Their investigation of the advancement and impediments involved in the achievement of the objectives of the Global Compacts and the ILO's decent work programme are analysed as the outcome of this relationship's positioning along the spectrum of 'cooperation-competition-clash'. With highly pertinent insights, the results of both intensive internal observation and interviews, these researchers reveal the complex interplay of fundamentally different institutional mandates and institutional design which impact the manner by which decent work for migrants is being, and can be, advanced. 
In the third paper, Guild and Barylska look at the implementation of the ILO's decent work agenda in one state, the UK, focusing in particular on the contradictory legislative agenda of different actors within the state which have resulted in the frustration of the agenda and the implementation of obstacles to decent work for migrant workers who have been designated by the state as irregular. In particular, they disentangle a complex set of national measures and court decisions which end up disenfranchising migrant workers while at the same time the executive continues to claim its successes in the implementation of ILO objectives. From the perspective of the Global Compacts ambition, endorsed by the UK, to achieve protection of migrants rights this is perhaps a problematic example.

In the fourth paper, Jones provides a rare and highly insightful examination of the intricate mechanisms of labour migration between Bangladesh and the Middle East by focusing on labour market intermediaries. This corridor, as it is known, is one of great concerns for the ILO as press exposés of exploitation of labour migrants have been rife. Among the most original aspects of this contribution is its forensic dissection of the role of the intermediaries, usually demonised as smugglers and traffickers or completely exonerated as international labour placement agencies. Instead of one or the other trope, Jones enters into the world of labour recruitment from the perspective of these agents' role in systemic and discriminatory deployment and employment practices. In doing so, this paper exposes the negative effects of removing the policy debate on 'fair recruitment' from the principle of non-discrimination, one of the key principles of the ILO's Decent Work concept, on the advancement of a rights-based and socially fair approach to global migration governance.

In the next (fifth) contribution, Lin and Nguyen focus on a specific pillar of decent work, social protection, in their discussion of the struggles for improved labour conditions in Vietnam and China as part of the aspiration towards decent work for migrant factory workers. Their rich ethnographic research provides new comparative insights into the similarities and nuanced differences between these two neighbouring countries whose rise to 'global factory' status has been predicated on the large pool of low-waged rural-to-urban migrant labour. The introduction of universal social security systems has been accompanied by increasing marketisation and the involvement of the private sector. This state of affairs shed doubts over equality of rights at work and entitlement to social protection as per the ILO's Decent Work Agenda.

The final two contributions examine global governance and global policy issues central to the decent work agenda and the objective of the Global Compacts to create conditions of equality for labour migrants in the national context of single states. Gore, in her ground-breaking work on migrant sex workers in Ghana, takes the angle of health rights to decent work in her exploration of the intersection between decent work, HIV and sex work as articulated through the ILO's programming. Health and sexual rights are also a core component of the Marrakesh Compact. The paper sheds light on how the shifting terrain of development policy interventions around sex work leads to a (dis)connect to/from the ILOAIDS programme and Decent Work Agenda. This opens up opportunities whilst also posing obstacles to civil society actors advocating for sex workers' rights. Based on the case of Cambodia, Brickell, Guermond, Lawreniuk, Natarajan and Parsons, on the other hand, focus on access to 
financial inclusion and its centrality to decent work as per the ILO program, through the lens of microfinance and its promotion primarily via private actors. By probing into the gap between rhetoric and reality in decent work policies, their paper exposes the problematic nature of the ILO's approach to microfinance as an 'invaluable tool' in achieving decent work for workers and their families. Drawing upon research findings from two types of internal migrants garment workers and brick makers-in Cambodia, they show how these migrant workers become vulnerable to exploitation as a result of the operation of financial services mechanisms. They conclude that excessive levels of microfinance lead to the erosion of, rather than contribution to, the prospect of decent work.

As a whole, this SI contributes highly nuanced discussions to the fledgling scholarship on global migration governance by providing new insights into the subject area of worker migration and the impact (or lack thereof) of both the ILO's decent work agenda and the Global Compacts. The papers together and individually demonstrate the importance of, whilst also highlighting the complexity involved in, coordinating global policy across multiple actors operating at various levels and sites, under conditions of competing interests and being subjected to political pressures, as the result of which the Decent Work Agenda for migrants is being realised in a piecemeal, inconsistent and selective manner, leading at times to contradictory or negative outcomes for migrant workers.

\section{Declaration}

Conflicts of interest The authors declare that they have no conflicts of interest to report. 